\title{
Chapter 13 \\ Land Degradation and Sustainable Land Management Innovations in Central Asia
}

\author{
Alisher Mirzabaev
}

\begin{abstract}
Land degradation affects about one-third of global terrestrial area and is having negative impacts on the incomes and food security of agricultural populations. The problem is also acute in the irrigated, rainfed and rangeland areas of Central Asia. There are numerous sustainable land management (SLM) technologies and practices which can help in addressing land degradation. However, many of these technologies have not been adopted at larger scales. The key underlying factors incentivizing SLM adoptions in Central Asia are found to be better access to markets, credit and extension, and secure land tenure. The adoption of SLM technologies can lead to improvements in income among agricultural households, especially the poor. However, SLM technologies alone cannot address land degradation in the region. SLM-friendly policies and institutions are essential.
\end{abstract}

Keywords Land degradation - Food security - Central Asia - Sustainable land management $\bullet$ Technology adoption

\section{Introduction}

Land degradation is a global problem affecting $29 \%$ of the global area across all agro-ecologies and 3.2 bln people around the world (Le et al. 2014), especially the poorest (Nachtergaele et al. 2010). The Central Asian countries of Kazakhstan, Kyrgyzstan, Tajikistan, Turkmenistan and Uzbekistan (Fig. 13.1) are also strongly affected by land degradation, with negative consequences on crop and livestock productivity, agricultural incomes, and rural livelihoods (Pender et al. 2009). The costs of land degradation in the region are substantial (Mirzabaev et al. 2015), with negative implications, especially on the livelihoods of the poorest rural agricultural households (ibid.).

Land degradation in the region is best analyzed along its major agro-ecological zones: secondary salinization is the biggest problem in the irrigated lands, soil erosion in the rainfed and mountainous areas, and loss of vegetation, desertification

\footnotetext{
A. Mirzabaev $(\bowtie)$

Center for Development Research (ZEF), University of Bonn, Bonn, Germany

e-mail: almir@uni-bonn.de 


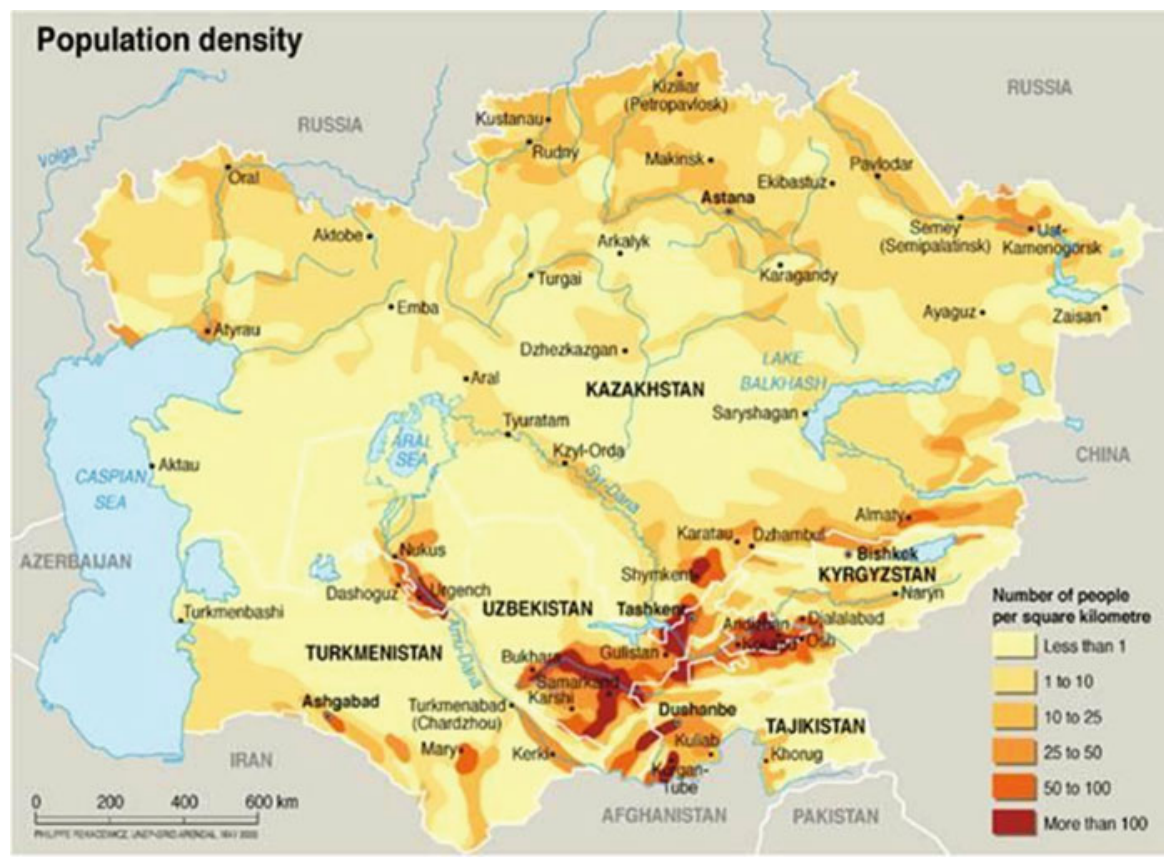

Fig. 13.1 Population density in Central Asia (Source: Philippe Rekacewicz, UNEP/GRIDArendal, http://www.grida.no/graphicslib/detail/population-density-central-asia_30dd)

or detrimental change in the vegetation composition in the rangelands (Gupta et al. 2009). Secondary salinization is estimated as covering from $40 \%$ to $60 \%$ of the irrigated areas in the region (Qadir et al. 2008), while 11 million ha of rainfed areas in Kazakhstan are affected by wind erosion (Pender et al. 2009). The rangelands cover about $65 \%$ of Central Asia (Mirzabaev 2013), of which 15-38 \%, depending on the country, have been found to have degraded between 1982 and 2006 (Le et al. 2014).

Land degradation affects the poorest parts of the region the hardest (Mirzabaev et al. 2015). In spite of this, the adoption of SLM technologies in Central Asia remains inadequate (Gupta et al. 2009), being especially low among poor agricultural households (Mirzabaev et al. 2015). This is despite the availability of many such technologies which have been demonstrated to be economically more profitable than traditional practices (Pender et al. 2009).

In this context, the present study seeks to answer two research questions:

1. What are the key constraints, drivers and impacts of SLM adoption in the region?

2. What are the lessons learnt from previous successful experiences of SLM adoption? 
To answer these questions, the existing literature on land degradation and sustainable land management in the region has been analyzed and systematically evaluated.

\section{The Conceptual Framework}

The current study is guided by the Economics of Land Degradation (ELD) conceptual framework developed in Nkonya et al. (2015) and von Braun et al. (2013). The conceptual framework (Fig. 13.2) categorizes the causes of land degradation into proximate and underlying, the interactions of which result in different levels of land degradation. Proximate causes of land degradation are those that have a direct effect on the terrestrial ecosystem, such as biophysical natural causes and unsustainable land management practices. The underlying causes of land degradation are those that indirectly affect the proximate causes of land degradation, such as institutional, socio-economic and policy factors (Nkonya et al. 2015).

Inaction against land degradation would lead to continuation, or even acceleration, of land degradation and its associated costs, including the losses in ecosystem services. The lack of appropriate integration of the value of ecosystem services into decision-making - because many of these services are not traded and have no market prices - would mean their value is equalized to zero, leading to more land degradation. However, besides its benefits, action against land degradation also involves costs (von Braun et al. 2013).

The conceptual framework also highlights the role of off-site costs and benefits of land degradation. The actions of individual land users are usually guided by the on-site costs of land degradation and on-site benefits from taking SLM actions. In case on-site costs of land degradation do not exceed the costs of adopting SLM, it may be economically irrational for landusers to adopt SLM practices. However, this lack of SLM adoption may result in significant off-site costs to be borne by third parties or by the society as a whole, necessitating public action for internalizing these externalities. In the case of the poor smallholder farmers often barely eking out their livelihoods from degrading lands, the application of the principle "the polluter pays" may not be feasible. Instead, there may be a need for supportive polices to encourage their adoption of SLM. As long as the social benefits from applying the SLM measures exceed the social costs incurred from incentivizing the land users to adopt them, such public interventions supporting SLM would still be socially more optimal than inaction. Moreover, as the experiences from around the world show, in many instances, poor smallholder landusers do not adopt SLM measures even when the adoption costs are much lower than the on-site benefits from SLM adoption. Thus, public action stimulating SLM is strongly justified, not only in terms of minimizing negative externalities of land degradation, but also for reducing poverty among smallholder landusers. 


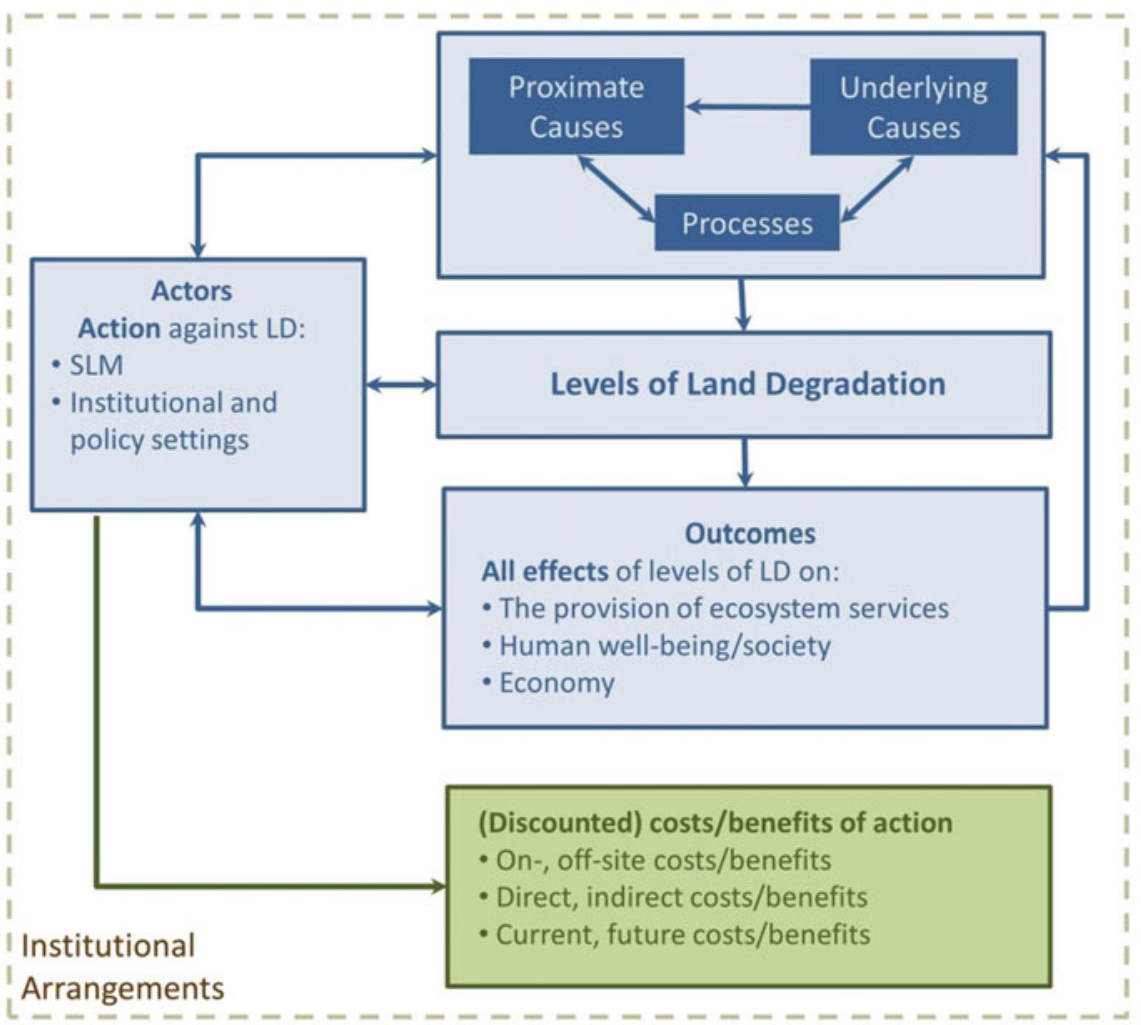

Fig. 13.2 The conceptual framework (Source: von Braun et al. (2013))

\section{Constraints, Drivers and Impacts of SLM Adoption in Central Asia}

The constraints to adoption of SLM technologies in the region are numerous and have varying salient features across the major agro-ecological zones (Table 13.1). However, the major constraints across all agro-ecologies seem to be similar. SLM adoption usually does not occur because of one single factor, but is a result of complex interaction of various drivers. For example, in irrigated areas, continued subsidies for irrigation create disincentives to economize on water and adopt watersaving technologies. Across all agro-ecologies, the lack of farmers' and pastoralists' awareness or training in use of appropriate practices, and the lack of adaptation of practices to local conditions, are considered major constraints, especially in combination with poorly functioning extension services (Gupta et al. 2009). The lack of access to credit inhibits the purchase of appropriate equipment, such as, for example, raised bed planters, or conservation agriculture machinery, such that farmers often have to rely on outdated and unproductive equipment from the Soviet 
Table 13.1 Factors constraining SLM adoption in Central Asia

\begin{tabular}{|c|c|c|c|}
\hline Irrigated & Rainfed & Rangeland & Mountainous \\
\hline $\begin{array}{l}\text { Population pressure, } \\
\text { low incomes }\end{array}$ & $\begin{array}{l}\text { Shortage of labor, } \\
\text { working capital and } \\
\text { capital assets, such as } \\
\text { new machinery }\end{array}$ & $\begin{array}{l}\text { Population pressure, } \\
\text { poverty among small- } \\
\text { scale herders }\end{array}$ & $\begin{array}{l}\text { Population pressure, } \\
\text { poverty }\end{array}$ \\
\hline $\begin{array}{l}\text { Subsidized irrigation } \\
\text { water }\end{array}$ & $\begin{array}{l}\text { Risk-averseness and } \\
\text { slow behavioral } \\
\text { change in upgrading to } \\
\text { more sustainable agri- } \\
\text { cultural practices (spe- } \\
\text { cifically, from } \\
\text { excessive tillage to } \\
\text { conservation } \\
\text { agriculture) }\end{array}$ & Lack of market access & $\begin{array}{l}\text { Lack of market } \\
\text { access }\end{array}$ \\
\hline $\begin{array}{l}\text { Land tenure } \\
\text { insecurity }\end{array}$ & $\begin{array}{l}\text { Mono-cropping } \\
\text { practices }\end{array}$ & $\begin{array}{l}\text { Breakdown of collec- } \\
\text { tive action institutions } \\
\text { regulating and facili- } \\
\text { tating access to } \\
\text { remote rangelands }\end{array}$ & $\begin{array}{l}\text { Breakdown of col- } \\
\text { lective action institu- } \\
\text { tions regulating and } \\
\text { facilitating access to } \\
\text { remote rangelands }\end{array}$ \\
\hline $\begin{array}{l}\text { Insufficient informa- } \\
\text { tion on SLM tech- } \\
\text { nologies, Poor } \\
\text { quality of agricul- } \\
\text { tural extension }\end{array}$ & $\begin{array}{l}\text { Insufficient informa- } \\
\text { tion on SLM technol- } \\
\text { ogies, Poor quality of } \\
\text { agricultural extension }\end{array}$ & $\begin{array}{l}\text { Insufficient informa- } \\
\text { tion on SLM technol- } \\
\text { ogies, Poor quality of } \\
\text { agricultural extension }\end{array}$ & $\begin{array}{l}\text { Insufficient informa- } \\
\text { tion on SLM tech- } \\
\text { nologies, Poor } \\
\text { quality of agricul- } \\
\text { tural extension }\end{array}$ \\
\hline $\begin{array}{l}\text { Lack of access to } \\
\text { credit for adopting } \\
\text { SLM }\end{array}$ & & $\begin{array}{l}\text { Shortage of herding } \\
\text { labor due to rural } \\
\text { out-migration }\end{array}$ & $\begin{array}{l}\text { Lack of access to } \\
\text { credit for adopting } \\
\text { SLM }\end{array}$ \\
\hline $\begin{array}{l}\text { Production and mar- } \\
\text { keting controls }\end{array}$ & & & $\begin{array}{l}\text { Shortage of labor due } \\
\text { to rural } \\
\text { out-migration }\end{array}$ \\
\hline $\begin{array}{l}\text { Institutional discon- } \\
\text { nections between } \\
\text { various levels of } \\
\text { water management }\end{array}$ & & & $\begin{array}{l}\text { Land tenure } \\
\text { insecurity }\end{array}$ \\
\hline
\end{tabular}

Sources: CACILM (2006a, b, c, d, e), Pender et al. (2009), Gupta et al. (2009), Kerven (2003)

era (ibid.). Agricultural production and marketing decisions for major crops are controlled by the governments in some countries, and market institutions are underdeveloped or lacking. Coupled with continuing land tenure insecurity, these limit producer incentives and serve as powerful deterrents to SLM adoption (Pender et al. 2009). In rangeland areas, effective pasture management mechanisms are lacking and pasture leasing is not clearly regulated in most countries in the region. Similarly, the interaction of lower disposable farm profits and low access to credit markets prevents farmers from investing in costly, but profitable in the long- term, technologies for sustainable land management. Poverty and low market access, especially in mountainous areas, but also in all other agro-ecologies, increase risk aversion and limit the available resources that could be invested in SLM. 


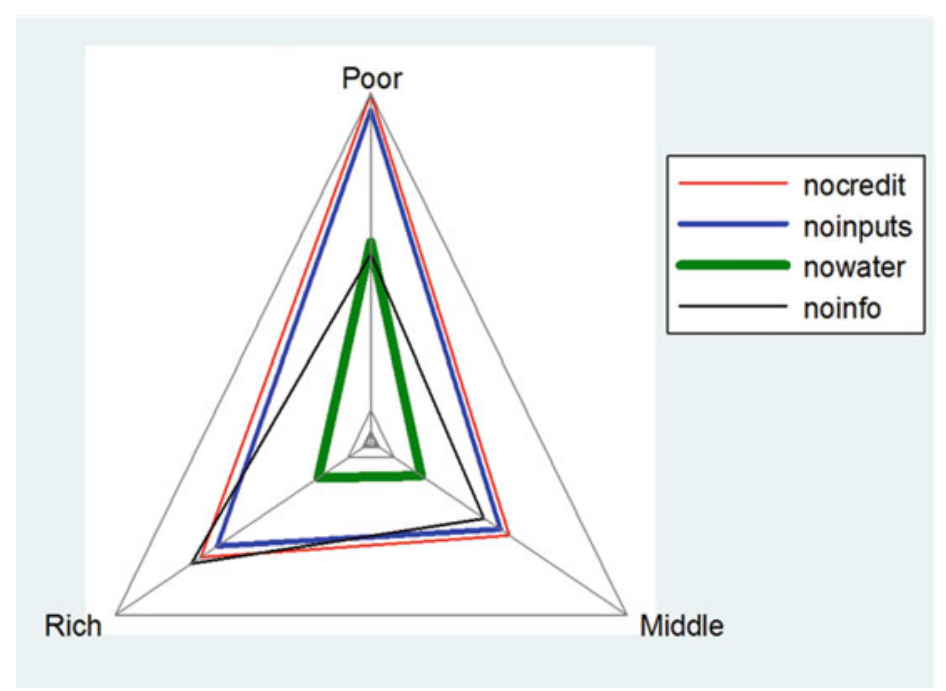

Fig. 13.3 Constraints on SLM adoption in Central Asia (Source: Mirzabaev (2013))

The above constraints and drivers of SLM adoption were based on expert evaluations. In this regard, it would also be important to look at household level evidence of the constraints on the adoption of SLM technologies. Analyzing the household level data from surveys, Mirzabaev (2013) indicates that major constraints for SLM adoption in the region pointed out by farming households themselves are lack of access to credit and affordable inputs, including water, but also lack of information about SLM technologies (Fig. 13.3). These factors seem to be especially constraining for the adoption of SLM technologies by poor farmers.

In this regard, it is also telling that the adoption of SLM practices was found to be lower among the poorest agricultural households (Fig. 13.4), despite the fact that these poorest households, in most cases, seem to be operating more degraded land than the richer households in the sample (Fig. 13.5).

More formally, analyzing these household surveys, Mirzabaev et al. (2015) find that key underlying factors incentivizing SLM adoption in Central Asia are better market access, access to extension, learning about SLM from other farmers, private land tenure among smallholder farmers, livestock ownership among crop producers, lower household sizes and lower dependency ratios. Better market access is likely to provide more incentives for increased production and productivity, making the opportunity cost of foregone benefits due to land degradation much higher, thus incentivizing the households for SLM adoption (ibid.). Similarly, access to extension is found to increase the number of SLM adoptions by increasing farmers' knowledge about SLM practices and their awareness of the benefits of SLM. The greater number of SLM technologies farmers know, the more SLM technologies they adopt (ibid.). 


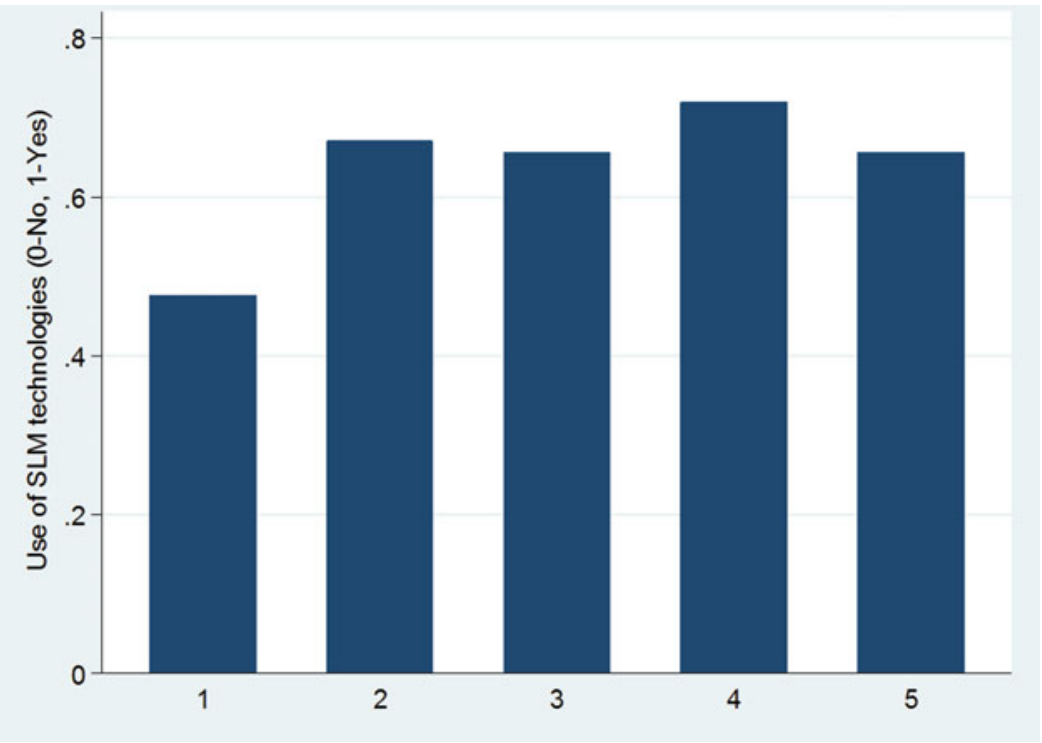

Fig. 13.4 Use of SLM technologies among agricultural households with different incomes. Note: categories: 1-poorest, . . . 5-richest (Source: Mirzabaev (2014))

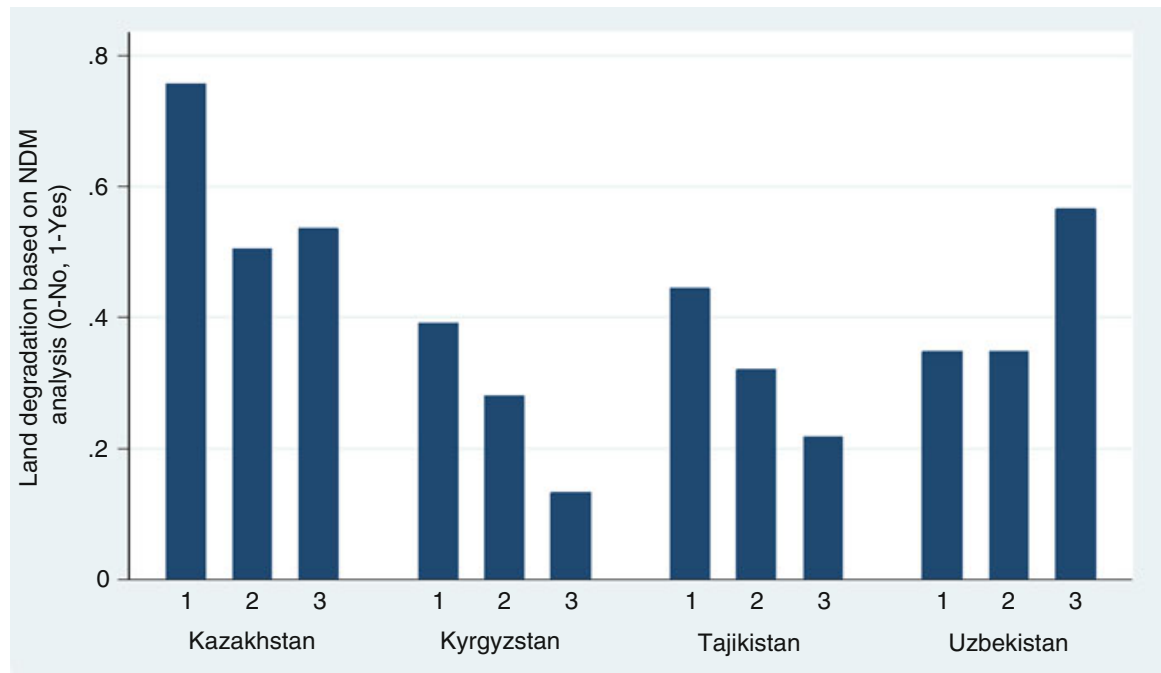

Fig. 13.5 Status of land quality among agricultural households of different incomes. Note: categories: 1-poor, 2-middle, 3-rich (Source: Mirzabaev (2014))

The adoption of SLM technologies could lead to better livelihood outcomes for the agricultural households, specifically the poorest $10 \%$ of them (Mirzabaev 2014). Each adopted SLM technology was found to be likely to increase the monetary value of per capita food consumption by $3 \%$ for the poorest $10 \%$ of 


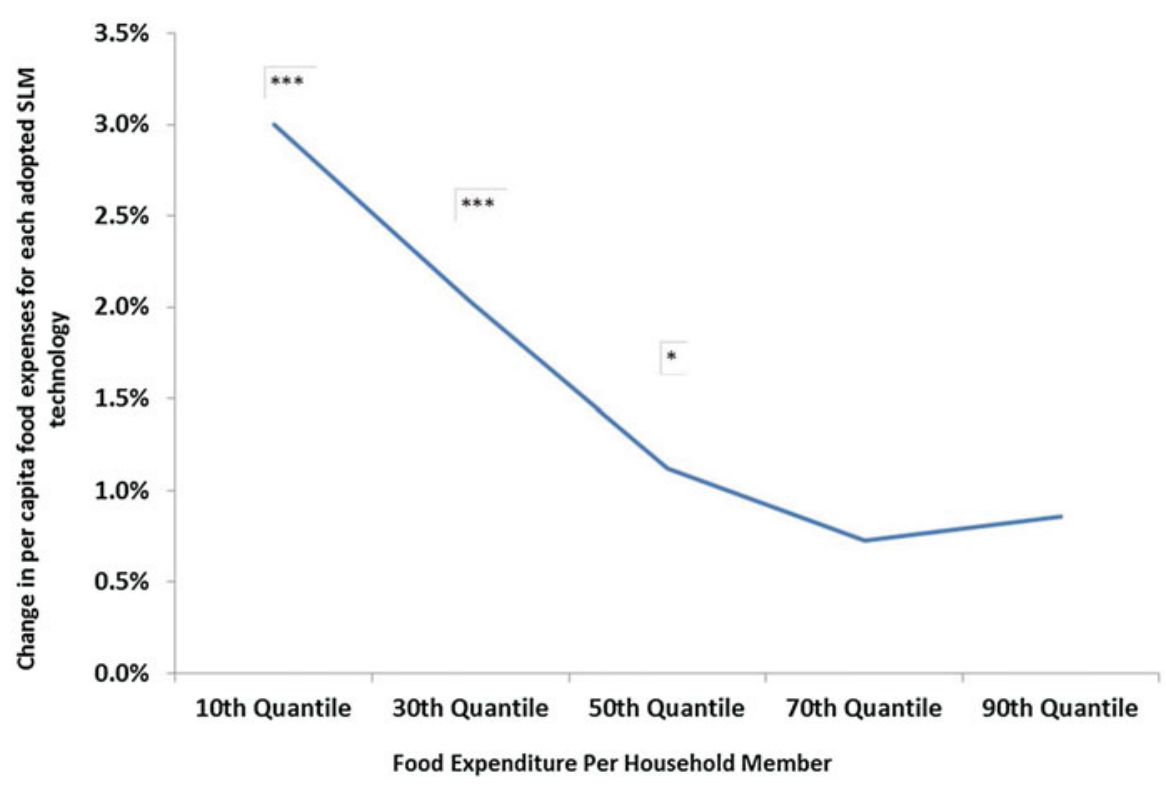

Fig. 13.6 Adoption of SLM technologies and per capita food expenses (Source: Mirzabaev (2014))

agricultural households, while the effect is less pronounced for the richer categories of agricultural households (ibid.: Fig. 13.6).

Summarizing these findings, the key factors incentivizing SLM adoption in Central Asia have been found to be better access to markets, credit and extension, and secure land tenure.

\section{Lessons Learnt from Previous Experiences}

The literature points to many available and economically viable sustainable land and water management practices that can help reduce land degradation and promote sustainable crop and livestock production in Central Asia (Gupta et al. 2009; Pender et al. 2009; Table 13.2).

Of particularly high potential are measures to increase the efficiency of irrigation water use: using such technologies as cutback and alternate furrow irrigation, raised bed cultivation, improved leaching methods, conjunctive or alternating use of drainage and fresh water, conservation tillage, and crop rotations and diversification. Other promising measures include use of soil and water conservation measures, organic soil fertility management practices, improved use of fertilizers, use of rock phosphate and phosphogypsum where these are useful and economical and 
Table 13.2 Major SLM technologies recommended in the literature for Central Asia

\begin{tabular}{l|l|l|l}
\hline Irrigated & Rainfed & Rangeland & Mountainous \\
\hline $\begin{array}{l}\text { Improved irrigation technologies } \\
\text { (cutback, alternate furrow, micro- } \\
\text { furrow, drip irrigation) }\end{array}$ & $\begin{array}{l}\text { Zero tillage and } \\
\text { direct seeding }\end{array}$ & Rotational grazing & $\begin{array}{l}\text { Strip } \\
\text { cropping }\end{array}$ \\
\hline Laser land levelling & Mulching & $\begin{array}{l}\text { Establishing } \\
\text { protected areas }\end{array}$ & $\begin{array}{l}\text { Drip } \\
\text { irrigation }\end{array}$ \\
\hline Permanent raised beds & $\begin{array}{l}\text { Water harvesting } \\
\text { and supplemen- } \\
\text { tary irrigation }\end{array}$ & Reseeding & $\begin{array}{l}\text { Use of plas- } \\
\text { tic chutes for } \\
\text { irrigation }\end{array}$ \\
\hline $\begin{array}{l}\text { Zero tillage, direct seeding, and } \\
\text { mulching }\end{array}$ & $\begin{array}{l}\text { Crop diversifica- } \\
\text { tion with legumes }\end{array}$ & $\begin{array}{l}\text { Planting halophytic } \\
\text { and drought- } \\
\text { tolerant plants }\end{array}$ & $\begin{array}{l}\text { Contour fur- } \\
\text { row } \\
\text { irrigation }\end{array}$ \\
\hline Crop diversification with legumes & Chemical fallow & $\begin{array}{l}\text { Increasing herd } \\
\text { mobility }\end{array}$ & Terracing \\
\hline $\begin{array}{l}\text { Use of phosphogypsum for sodic } \\
\text { soils }\end{array}$ & $\begin{array}{l}\text { Continuous } \\
\text { cropping without } \\
\text { summer fallow }\end{array}$ & $\begin{array}{l}\text { Integrated crop- } \\
\text { livestock-range- } \\
\text { land management }\end{array}$ & \\
\hline $\begin{array}{l}\text { Tree plantations and bio-drainage, } \\
\text { Planting halophytic plants (ex, } \\
\text { licorice) }\end{array}$ & Use of fertilizers & Chemical fallow & \\
\hline
\end{tabular}

Sources: Mirzabaev (2014), who compiled from Gupta et al. (2009), Pender et al. (2009), Toderich et al. (2002), Toderich et al. (2008a, b), Lamers and Khamzina (2008), Lamers et al. (2009), ICARDA $(2002,2003,2004,2005,2006)$

improved rangeland and fodder management (ICARDA 2002, 2003, 2004, 2005, 2006).

The impacts of most of these measures are highly context-dependent (Pender et al. 2009). Despite the higher profitability of many of these technologies as compared to traditional practices, the adoption has been limited (ibid). This is due to the large number of factors highlighted in the section above. For example, Pender et al. (2009) indicate that raised bed planters may cost about $\$ 4000$ (US) to import from India (as there is no local production). Although the annualized cost per hectare of such equipment is low, the high initial cost could be prohibitive for individual smallholder farmers, requiring adequate credit, collective action or development of lease markets to make this equipment accessible (ibid.).

However, despite many constraints, there have been two major successful new technology adoptions in the region over the last two decades, which can provide lessons on the adoption of SLM practices. The first is the planting of winter wheat among standing cotton, instead of the earlier practice of removing the cotton stalks, tilling the land and only then planting the winter wheat. This practice has now been widely adopted in almost all irrigated cotton-winter wheat crop rotations in the region, especially in Uzbekistan. The second is the spread of reduced and zero till technologies in northern Kazakhstan for rainfed production of grain crops (Kienzler et al. 2012). Both of these technologies are now applied on millions of hectares in the region. 
In both cases, the wide-scale adoption seems to have been made possible by the confluence of several factors, such as strong government support, strong market incentives, availability of local expertise and the national agricultural research systems actively working to develop these technologies. To illustrate, the Government of Uzbekistan was quick in taking up the technology of direct wheat planting into standing cotton developed by the national agricultural research system and has broadly mandated the use of the technology starting from early 1990s. Until that time, cotton was by far the single most important crop planted in the country. However, with the collapse of trade and mutual exchanges after the break-up of the Soviet Union, the need emerged to develop national wheat production rapidly to maintain food security in the country. Millions of hectares were shifted from cotton to wheat in a matter of a couple of seasons. The crop calendars for cotton and winter wheat left a very narrow window between the harvest of cotton in the fall and the planting of winter wheat. Moreover, additional tillage operations also required massive use of scarce fuel resources. These three factors, lack of time between cotton harvest and winter wheat planting and fuel savings, plus strong Government mobilization, have led to rapid adoption of this technology throughout Uzbekistan. Similarly, conservation agriculture and its elements have been researched in Kazakhstan for many decades. Some elements, such as reduced tillage, were adopted even during the Soviet times. From the 1990s, there have been massive research and demonstration efforts regarding zero tillage by the national and international agricultural centers working in the country, but without much widescale adoption until the early-to-mid 2000s, when the Government of Kazakhstan provided subsidies the equivalent of about $\$ 7$ (US) per ha for the adoption of conservation agriculture practices in the country. Although this amount seems quite small, coupled with significant cost savings in fuel use, especially in the context of super-sized rainfed farms in the north of the country, this incentive has proved to be crucial in rapid spread of conservation tillage in the country, reducing soil erosion and making grain production more resilient to recurrent droughts in northern Kazakhstan (Kienzler et al. 2012).

So, these experiences yield the lesson that the availability of SLM technologies is, of course, vital. However, in the context of Central Asia, at least, but probably also beyond, wide-scale adoption requires cooperation between the Governments, research institutes, and extension services, and all these should be supported by market forces and farmer incentives, and not work against the latter. To give a different example, the Governments in the region have been trying to promote drip irrigation through subsidies and soft loan programs. However, the success of these initiatives has so far been limited. The water is not priced and its supply is highly subsidized in the region. In such a context, drip irrigation loses its major attraction, i.e., saving water resources; because water is free, there are no incentives to save it at the individual farm level, even if there are strong incentives to save water at the national level since, in the context of water scarcity, overuse in upstream areas would mean lack of water in downstream areas. 


\section{Conclusions}

The key underlying factors incentivizing SLM adoption in Central Asia are found to be better market access, access to extension and credit, access to well-informed peer networks among farmers, private land tenure among smallholder farmers, and livestock ownership among crop producers. Adopting SLM technologies could have positive impacts on rural household food consumption, especially among the poorest. However, SLM technologies alone cannot address land degradation in the region. SLM-friendly policies and institutions are essential. The examples of success stories of sustainable land management reviewed here have occurred as a result of the combination and interaction of technological, social and economic changes, achieved through synergies of bottom-up and top-down approaches in the region.

Open Access This chapter is distributed under the terms of the Creative Commons AttributionNoncommercial 2.5 License (http://creativecommons.org/licenses/by-nc/2.5/) which permits any noncommercial use, distribution, and reproduction in any medium, provided the original author(s) and source are credited.

The images or other third party material in this chapter are included in the work's Creative Commons license, unless indicated otherwise in the credit line; if such material is not included in the work's Creative Commons license and the respective action is not permitted by statutory regulation, users will need to obtain permission from the license holder to duplicate, adapt or reproduce the material.

\section{References}

Central Asian Countries Initiative for Land Management (CACILM) (2006a) Republic of Kazakhstan national programming framework. Prepared by UNCCD National Working Group of the Republic of Kazakhstan. Draft, 01 Feb 2006

CACILM (2006b) Republic of Kyrgyzstan national programming framework. Prepared by UNCCD national working group of the Kyrgyz Republic. Draft, 01 Feb 2006

CACILM (2006c) Republic of Tajikistan national programming framework. Prepared by UNCCD National working group of the Republic of the Republic of Tajikistan. Draft, 14 Mar 2006

CACILM (2006d) Turkmenistan national programming framework. Prepared by Turkmenistan UNCCD national working group. 28 Febr 2006

CACILM (2006e) Republic of Uzbekistan national programming framework. Prepared by Republic of Uzbekistan UNCCD national working group. Draft, 28 Feb 2006

Gupta R, Kienzler K, Mirzabaev A, Martius C, de Pauw E, Shideed K, Oweis T, Thomas R, Qadir M, Sayre K, Carli C, Saparov A, Bekenov M, Sanginov S, Nepesov M, Ikramov R (2009) Research prospectus: a vision for sustainable land management research in Central Asia. ICARDA Central Asia and Caucasus program, Sustainable agriculture in Central Asia and the caucasus series no 1. CGIAR-PFU, Tashkent, $\mathrm{p} 84$

ICARDA (2002) Integrated feed and livestock production in the steppes of Central Asia. Project annual report (2001-2002), IFAD technical assistance grant (TAG): ICARDA-425. International Center for Agricultural Research in the Dry Areas, Beirut, p 207

ICARDA (2003) On-farm soil and water management for sustainable agricultural systems in Central Asia, ADB-RETA 5866. Tashkent

ICARDA (2004) Annual report. Improving rural livelihoods through efficient on-farm water and soil fertility management in Central Asia. Phase II (2004-2006) Project supported by ADB: RETA 6136. Tashkent 
ICARDA (2005) Annual report. Improving rural livelihoods through efficient on-farm water and soil fertility management in Central Asia. Phase II (2004-2006) Project supported by ADB: RETA 6136. Tashkent

ICARDA (2006) Annual report. Improving rural livelihoods through efficient on-farm water and soil fertility management in Central Asia. Phase II (2004-2006) Project supported by ADB: RETA 6136. Tashkent

Kerven C (ed) (2003) Prospects for pastoralism in Kazakhstan and Turkmenistan: from state farms to private flocks. Routledge Curzon, London, p 276

Kienzler KM, Lamers JPA, McDonald A, Mirzabaev A, Ibragimov N, Egamberdiev O, Ruzibaev E, Akramkhanov A (2012) Conservation agriculture in Central Asia - what do we know and where do we go from here? Field Crops Res 132:95-105

Lamers JPA, Khamzina A (2008) Woodfuel production in the degraded agricultural areas of the Aral Sea Basin, Uzbekistan. Bois et Forêts des Tropiques 297:47-57

Lamers JPA, Bobojonov I, Khamzina A, Franz J (2009) Financial analysis of small-scale forests in the Amu Darya Lowlands, Uzbekistan. Forests, Trees and Livelihoods (Accepted Vol 19-1)

Le QB, Nkonya E, Mirzabaev A (2014) Biomass productivity-based mapping of global land degradation hotspots. ZEF Discussion Papers No 192. Center for Development Research, Bonn, Feb 2014, p 42

Mirzabaev A (2013) Climate volatility and change in Central Asia: economic impacts and adaptation. Doctoral thesis at Faculty of Agriculture, University of Bonn, Bonn

Mirzabaev (2014) Building the resilience of the poor through sustainable land management. Presentation during the IFPRI 2020 resilience conference side-event on 15 May 2014 in Addis Ababa, Ethiopia

Mirzabaev A, Goedecke J, Dubovyk O, Djanibekov U, Nishanov N, Aw-Hassan A (2015) Economics of land degradation in Central Asia. In: Nkonya E, Mirzabaev A, von Braun J (eds) The economics of land degradation and improvement - a global assessment for sustainable development. Springer, Dordrecht

Nachtergaele F, Petri M, Biancalani R, Van Lynden G, Van Velthuizen H (2010) Global Land Degradation Information System (GLADIS). Beta Version. An information database for land degradation assessment at global level, Land degradation assessment in Drylands technical report No 17. Food and Agriculture Organization of the United Nations, Rome

Nkonya E, Mirzabaev A, von Braun J (2015) The economics of land degradation, and improvement - a global assessment for sustainable development. Springer, Dordrecht

Pender J, Mirzabaev A, Kato E (2009). Economic analysis of sustainable land management options in Central Asia, Final report for the ADB. International Food Policy Research Institute and International Center for Agricultural Research in the Dry Areas, Washington DC/Beirut

Qadir M, Noble AD, Qureshi AS, Raj Gupta, Yuldashev T, Karimov A (2008) Land and water quality degradation in Central Asia: a challenge for sustainable agricultural production and rural livelihoods. (Submitted)

Toderich K, Tsukatani T, Mardonov B, Gintzburger G, Zemtsova O, Tsukervanik E, Shuyskaya E (2002) Water quality, cropping and small ruminants: a challenge for the future agriculture in dry areas of Uzbekistan, Discussion paper No 553. Kyoto Institute of Economic Research, Kyoto University, Kyoto

Toderich K, Tsukatani T, Shoaib I, Massino I, Wilhelm M, Yusupov S, Kuliev T, Ruziev S (2008a) Extent of salt-affected land in Central Asia: biosaline agriculture and utilization of salt-affected resources, Discussion paper No 648. Kyoto Institute of Economic Research, Kyoto

Toderich K, Shoaib I, Juylova E, Rabbimov A, Bekchanov B, Shuyskaya E, Gismatullina L, Osamu K, Radjabov T (2008b) New approaches for biosaline agriculture development, management and conservation of sandy desert ecosystems. In: Abdelly C, Ozturk M, Ashraf M, Grignon K (eds) Biosaline agriculture and high salinity tolerance. Birkhäuser Verlag, Basel

von Braun J, Gerber N, Mirzabaev A, Nkonya E (2013) The economics of land degradation, ZEF working paper 109. Center for Development Research, Bonn 